\title{
School Climate: Its Impact on Teachers' Commitment and School Performance
}

\author{
Vilma H. Manla $(D)$ \\ Doctor of Education- Major in Educational Management, Teacher III, Quirino Primary School, Department of Education, Philippines \\ $\square$ Corresponding Author: Vilma H. Manla, E-mail: vilma.manla@deped.gov.ph
}

\section{ARTICLE INFORMATION}

Received: December 14, 2020

Accepted: February 17, 2021

Volume: 3

Issue: 2

DOI: 10.32996/jweep.2021.3.2.3

\section{KEYWORDS}

School Climate, Teachers'

Commitment, School Performance, Teacher Affiliation, Institutional Integrity, Collegial Leadership, Resource Influence, Academic Emphasis

\section{ABSTRACT}

The aims of this study were to determine the perceptions of school climate, teachers' commitment and school performance held by principals, teachers and parents and the relationship among these variables. Thirty elementary schools of the third congressional district of Bohol consisting of 200 teachers, 30 principals and 60 parents who were randomly sampled took part in the study. The teachers and parents completed two survey instruments: Organizational Health Inventory for elementary schools (OHI-E) from Hoy and Tarter to examine school climate and Organizational Commitment Questionnaire (OCQ)from Celep to test teachers' commitment, while the principals were made to answer an additional questionnaire that solicits data regarding the school performance. With the school as the unit of analysis, the OHI-E outlined and measured five elements related to school climate (teacher affiliation, institutional integrity, collegial leadership, resource influence and academic influence). Those five were the independent variables used for the study. The dependent variables were the teachers' commitment with regard to the commitment to school, teaching profession, pupils and work group; and school performance measured by graduation, retention, promotion, participation, repetition, failure, drop-out rates and the National Achievement Test Result. Data were analyzed using frequency count and simple percentage calculation. Weighted mean score was used to assess the level of school climate, teachers' commitment and school performance. Furthermore, parametric test like Pearson Product-Moment Correlation (rxy) was used to determine the degree of relationship between school climate and the teachers' commitment; while Spearman Rank Correlation ( $r s$ ) was used to determine the relationship of school climate and school performance. Results indicated that school climate is related to teachers' commitment and school performance. These findings have significant implications for the implementation of change in schools, motivation, productivity, well-being, and learner achievement.

\section{Introduction}

The climate in a school can either make everything possible or not make everything possible (Hinduja, 2012). It is true that instruction and curriculum are important, but neither can be effective unless the climate of the school is centered on respect, clear expectations, personal responsibility, and recognition.

Having taught for more than nine years, the researcher has construed that the working environment affects the teachers' commitment and students' performance which affects the schools' performance as a whole. Osher et al. (2008) suggests that there are powerful social and emotional factors that affect learning. These include how the student experiences, his or her relationships with the teachers and other students as well as how they experience the care and support provided to teachers, principals and other staff.

K C AL-KINDI CENTER $\mathbf{R}$ FOR RESEARCH AND $\mathbf{R}$ D DEVELOPMENT Your gateway to world-class research

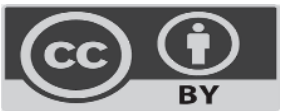

Published by Al-Kindi Center for Research and Development. Copyright (c) the author(s). This open access article is distributed under a Creative Commons Attribution (CC-BY) 4.0 license 
A school climate that supports collaboration and teacher participation in decision-making is most strongly related to higher morale, stronger commitment to teaching, and intentions to remain in the profession. Having a highly committed teacher is regarded as an asset in any school. A committed teacher is likely to be more hard-working, less tardy and less inclined to leave the workplace.

However, the phenomenon of teacher commitment attracted research attention in different parts of the world because of its implications for teacher retention (Troman, 2013). Some researchers suggest that novice teachers in the $21^{\text {st }}$ century show less commitment in teaching (Mayer, 2006). As a result, teacher absenteeism increased, and some teachers started to search for new schools or revisited their commitment to teaching, others considered leaving the profession (Joffres et al., 2001).

In relation to this, understanding the teachers' level of commitment is crucial because it reflects the teachers' involvement in school and the degree to which it affects its performance. Due to the importance of positive school climate and teacher commitment on educational outcome, a better understanding related to its conceptualization is needed.

This study aimed to determine the perceptions of school climate, teachers' commitment and school performance held by principals, teachers and parents and the relationship among these variables. Specifically, this study is guided with the following objectives: to determine the level of school climate in terms of Teacher Affiliation, Institutional Integrity, Collegial Leadership, Resource Influence, and Academic Emphasis; the level of teachers' commitment towards school, teaching profession, pupils and work group; the level of school performance; and the relationship between school climate and teachers' commitment and school performance. Thirty elementary schools of the third congressional district of Bohol consisting of 200 teachers, 30 principals and 60 parents who were randomly sampled took part in the study. The study used a descriptive correlational design in which the relationship between school climate and teachers' commitment, and its impact on school performance was explored. However, it is important to acknowledge the limitations of this study. Only the principals, teachers and parents were included as respondent. Therefore, the voice of the pupils was not considered in the light of this study.

\section{Literature Review}

To build up ideas that there may be relationship between school climate, teachers' commitment and school performance, it is logical to examine various school climate variables and essentials in acquiring high teacher commitment and good school performance. Therefore, this portion deals with laws, mandates or directives, republic acts, literatures and studies pertaining school climate and the its impact on teachers' commitment and school performance.

If the school is deemed the agent of change towards producing quality human capital for the nation, then school climate is one very important factor that influences the success. Raman (2015) claimed that school climate portrays the personality of an individual and how that individual works towards achieving school success.

School climate refers to factors that contribute to the tone in schools, and the attitudes of staff and students toward their schools. Thus, school climate is viewed as part of the school environment associated with attitudinal and affective dimensions and the belief systems of the school that influence children's cognitive, social, and psychological development (Griffith, 2000).

Research has demonstrated that there are many variables that contribute to influencing a school's success, which include instructional strategies, classroom resources, school culture, or current school climate, as well as the instructional leadership and administrative support (Brookover et al., 1978). Although each of these may have a direct or indirect impact on school success, Esposito (2019) claimed that overall school climate significantly predicts school adjustment and outcomes.

With these findings, the government exerts its utmost effort in supporting the nation's goal of providing a positive climate that supports holistic students' development and elicits teachers' motivation and commitment. It is clear and evident in the provisions of the following laws and Republic Acts:

Article II, Section 1 of the Code of Ethical and Professional Standard for Professional Teacher states that the schools are nurseries of future citizens of the State, each teacher is a trustee of the cultural and educational heritage of the nation and is under obligation to transmit to learners such heritage, as well as to evaluate national morality, promote national pride, cultivate love of country, instill allegiances to the constitution and respect for all duly constituted authorities and promote obedience to the law of the State (Sarmiento, 2002).

Furthermore, Section 4 of the Implementing Rules and Regulations of Republic Act No. 10627, otherwise known as the AntiBullying Act of 2013 states that all public and private kindergarten, elementary and secondary schools shall adopt policies to address the existence of bullying in their respective institutions by fostering positive school climate and environment conducive to the attainment of learning objectives, the development of healthy relationships and the understanding of and respect for 
individual differences. As such, Section 7 of the same act recommended that there shall be intervention programs to promote the continuity of comprehensive anti-bullying policies.

Moreover, Article II, Section 17 of the Batas Pambansa Bilang 232 also known as the "Education Act of 1982" states that every school administrator shall develop and maintain a healthy school atmosphere conducive to the promotion and preservation of academic freedom and effective teaching and learning, and to harmonious and progressive school-personnel relationship.

Section 2 of the Republic Act No. 9155 otherwise known as the "Governance of Basic Education Act of 2001" provided that schools and learning centers shall be empowered to make decisions on what is best for the learners they serve. As such, the school heads shall have authority, accountability and responsibility in creating an environment within the school that is conducive to teaching and learning and in encouraging staff development to ensure quality outcomes.

Section 2 of the DepEd Order \# 40 s. 2012 otherwise known as the "DepEd Child Protection Policy" states that the Department of Education shall ensure that all schools are conducive to the education of children. The best interest of the child shall be the paramount consideration in all decisions and activities involving children.

With an increasing interest in how school climate affects student and teacher performance and more specifically how school leaders can help shape their school's climate, several studies have been conducted. Barth (2001) provided an analysis, stating that, "A school's culture has far more influence on life and learning in the schoolhouse than the department of education, superintendent, the school board, or even the principal can have". These studies have previously been backed up by several literatures back then. In "Improving School Climate and School Culture", Haynes (1997) provide additional support to school climate's impact on staff productivity and student achievement. They said that while school culture encompasses the collective norms and traditions of the school environment, school climate is "the heart and soul of a school".

Kelley (2005) declared that there is a relative direct connection between the school climate and the employees' productivity and the organization's performance. Positive work environment makes workers feel productive, motivated, energized, effective, and committed in their workplaces.

Hoy and Tarter (1992) as cited by Thomasson (2006), identified general climate variables. These are (1) Teacher Affiliation, (2) Institutional Integrity, (3) Collegial Leadership, (4) Resource Influence, and (5) Academic Emphasis. These factors are discussed hereunder:

Teacher Affiliation refers to a sense of friendliness among the staff and between students and teachers. It also refers to the sense of commitment teachers feel towards their students and to the mission of the school.

Institutional Integrity measures the degree to which the educational mission of the school can go forward without undue influence from outside groups.

Collegial Leadership refers to the perceived behavior of the principal. Schools which score high on this factor have principals who set an open, friendly, and supportive tone, yet hold high expectations for performance of teachers and students.

Resource Influence describes the ability of the principal to influence superiors to provide adequate classroom supplies in a timely manner.

Academic Emphasis is the school's emphasis on achievement. Teachers have high expectations and students meet these high expectations through hard work and cooperation.

Anyone who spends time in schools quickly discovers how one school can feel different from other schools. School climate is a general term that refers to the feel, atmosphere, tone, ideology, or milieu of a school. Thus, school climate is a relatively enduring character of a school that is experienced by its participants, that affects their actions, and that is based on the collective perceptions of behavior in the school (Hoy, 2001).

Yusof (2012) claimed that a happy school is very motivated, with productive accomplishment which made it different from other schools. He defined school climate as a school's social environment and culture which influence the behavior of its community. This means that school climate plays an important role in influencing the behavior and achievement of the community in the school. 
In a healthy school climate, the leader is able to influence the teachers and develop their belief that they have an impact on learning and teaching. Yusof (2012) claimed that the characteristics of a school may affect teachers' commitment.

Teachers might have several forms of commitment that are related to the strength of psychological attachment or the identification with the focus of commitment. (Ibrahim et al., 2013). Teachers' behavior might vary depending on the types of commitment they emphasized (Cohen, 2000; Firestone \& Pennell, 1993; Somech \& Bogler, 2002). The earlier study by Singh and Billingsley (1998) suggested that there are multiple forms of Teacher Commitment. Specifically, Louis (1998) explained four types of Teacher Commitment based on the research work done by Firestone and Rosenblum (1988) as well as Louis and Smith (1990). Louis highlighted the dimension of Commitment to School, viewing from the sociological perspective by creating a sense of community and personal caring among school individuals; Commitment to Academic Goals by exerting more efforts for nurturing high expectations on student achievement; Commitment to Students by understanding and awareness of adolescent development as unique whole individuals; and Commitment to Teaching reflects a high degree of psychological attachment with teachers' duty in their classroom (Coladarci, 1992).

Smith (2009) stated that teachers who obtain support from their leaders are more inclined to be committed to the vision and the mission of the school including the school values. Raman et al. (2015) denoted commitment towards an organization as "a strong belief and acceptance of the aims and values, readiness to work diligently to represent the organization and clear desire to stay as the member of the organization". Schools that have dedicated teachers who are committed to the school will become effective schools. Peterson and Skiba (2000) exclaimed that a school that have happy climate help in increasing teachers' commitment towards the school.

Empirical evidence has linked school climate with achievement. A growing body of research suggests that school climate may be an important variable in explaining why some schools are more successful than others. School climate includes such factors as a school's order, safety, and discipline; supports for teaching and learning; personal and social relationships; and school connectedness. Results provide new evidence that an authoritative or positive school climate is associated with high school academic achievement. (Konold et al. 2018).

School climate has been widely recognized as an important component of successful schools and a predictor of a variety of student outcomes (Keith, 2005). Researchers and practitioners commonly agree that climate is an important factor in determining the success of a school.

A healthy school climate contributes to effective teaching and learning. Providing a positive and supportive work environment and climate for faculty and staff, more often than not, improves faculty, staff and student performance (Freiberg, 2008). Previous research regarding this construct has repeatedly demonstrated positive relationship between school climate and academic achievement, as well as decreased instances of misconduct and aggression (Dee et al. 2006).

Teachers who are highly dedicated and committed will complete their task to the best of their effort because they understand that they are the main player in the implementation of the curriculum.

Cohen et al. (2009) stated that school climate affects its success. Previous researchers claimed that an organization climate affects the behavior of the organization members. Thus, school climate is said to also affect teachers' behavior. Therefore, teachers who are committed towards the teaching and learning process will affect the school's performance.

Reinforcing the findings, Payne (2018) stated that schools with positive climates meet the needs of both teachers and students, who therefore become more attached to other school community members, more committed to the school's mission and goals and are more likely to internalize school norms and rules. Ebrahimi et al. (2014) conducted a study examining the importance of organization climate on teachers' involvement in schools and found that teachers need conducive organization climate to encourage them to complete their tasks.

If the school climate is transparent and positive, teachers will feel comfortable doing their jobs with their colleagues; and if they have leaders who are considerate and give attention to the needs of the subordinates, teachers will be motivated because they know that they are fully supported especially when they are going through rough patches. Shirzadi et al. (2013) claimed that by providing suitable or conducive climate at working place, the tendency to stay loyal and committed will increase.

This study of school climate, teachers' commitment and school performance could be one of the most significant studies not only now but in the future as well, for it is through understanding the schools' physical and psychological environment where realization of providing a positive and supportive work for students, faculty and staff can be spelled. This is based on the fact that the school is a laboratory for real life and an agent for change and socialization. 


\section{Methodology}

The study used a descriptive correlational design in which the relationship between school climate and teachers' commitment, and its impact on school performance was explored.

A questionnaire was used as data gathering tool. The first part was on school climate data which was gathered using the Organizational Health Inventory for elementary schools (OHI-E) by Hoy and Tarter (2001). The instrument measures five variables; Teacher Affiliation, Institutional Integrity, Collegial Leadership, Resource Influence, Academic Emphasis.

The second part was adapted from the Organizational Commitment Questionnaire developed by Celep (2009) that relates to teachers' commitment in school to measure organizational commitment. Some questions were modified to fit the objectives of the study. And the last part pertains to the school performance as measured by its graduation, repetition, dropout, retention, failure, promotion, and participation rates.

Data were analyzed using frequency count and simple percentage calculation. Weighted mean was used to assess the level of school climate, teachers' commitment and school performance.

Parametric test like Pearson Product-Moment Correlation $\left(r_{x y}\right)$ was used to determine the degree of relationship between school climate and the teachers' commitment; while Spearman Rank Correlation $\left(\mathrm{r}_{\mathrm{s}}\right.$ ) was used to determine the relationship of school climate and school performance. Furthermore, linear regression was performed to determine the influence of teachers' profile to their level of commitment.

\section{Results and Discussion}

Table 1.1 Level of School Climate in terms of Teacher Affiliation

\begin{tabular}{|c|c|c|c|c|c|c|}
\hline \multirow[b]{2}{*}{ SCHOOL CLIMATE } & \multicolumn{4}{|c|}{ Weighted Mean Score } & \multirow[b]{2}{*}{$\mathrm{R}$} & \multirow{2}{*}{ DI } \\
\hline & $\mathrm{T}$ & $\operatorname{Pr}$ & $\mathrm{Pa}$ & Ave & & \\
\hline \multicolumn{7}{|l|}{ Teacher Affiliation } \\
\hline 1. Teachers help and support each other. & 3.7 & 4.0 & 4.0 & 3.9 & 1 & $\mathrm{AO}$ \\
\hline $\begin{array}{l}\text { 2. Teachers respect the professional competence of their } \\
\text { colleagues. }\end{array}$ & 3.8 & 4.0 & 3.9 & 3.9 & 1 & $\mathrm{AO}$ \\
\hline 3. The interactions between faculty members are cooperative. & 3.7 & 3.9 & NA & 3.8 & 2 & $\mathrm{AO}$ \\
\hline 4. Teachers in this school exercise professional judgment. & 3.7 & 3.9 & NA & 3.8 & 2 & $\mathrm{AO}$ \\
\hline 5. Teachers provide strong social support for colleagues. & 3.6 & 3.9 & NA & 3.8 & 2 & $\mathrm{AO}$ \\
\hline 6. Teachers are committed to their students. & 3.9 & 3.9 & 4.0 & 3.9 & 1 & $\mathrm{AO}$ \\
\hline 7. Teachers "go the extra mile" to help their students. & 3.6 & 3.8 & NA & 3.7 & 3 & $\mathrm{AO}$ \\
\hline 8. Teachers in this school like each other. & 3.6 & 3.8 & NA & 3.7 & 3 & $\mathrm{AO}$ \\
\hline 9. Teacher exhibits friendliness to each other. & 3.8 & 3.9 & 3.9 & 3.9 & 1 & $\mathrm{AO}$ \\
\hline 10. Teachers accomplish their work with enthusiasm. & 3.7 & 3.8 & 3.8 & 3.8 & 2 & $\mathrm{AO}$ \\
\hline 11. There is a feeling of trust and confidence among the staff. & 3.6 & 3.7 & 3.7 & 3.7 & 3 & $\mathrm{AO}$ \\
\hline AVERAGE WEIGHTED MEAN & 3.7 & 3.9 & 3.9 & 3.8 & & $\mathrm{AO}$ \\
\hline
\end{tabular}

Items 1, 2, 6 and 9 got the highest average weighted mean of 3.9 described as "always observed" while items 7, 8 and 11 got the lowest average weighted mean of 3.7, still described as "always observed". Findings revealed that the school is "very healthy" since all teachers, principals and parents felt that there is "always" a sense of friendliness among the staff and between students and teachers. It also means that teachers felt a sense of commitment towards their students and to the mission of the school.

Table 1.2 Level of School Climate in terms of Institutional Integrity

\begin{tabular}{|c|c|c|c|c|c|c|}
\hline \multirow{2}{*}{$\begin{array}{c}\text { SCHOOL CLIMATE } \\
\text { Institutional Integrity }\end{array}$} & \multicolumn{4}{|c|}{ Weighted Mean Score } & \multirow{2}{*}{$\mathbf{R}$} & \multirow[b]{2}{*}{ DI } \\
\hline & $\mathbf{T}$ & $\operatorname{Pr}$ & $\mathbf{P a}$ & Ave & & \\
\hline 1. Influential parents cannot change the school policy. & 3.4 & 3.5 & 3.5 & 3.5 & 2 & $\mathrm{AO}$ \\
\hline 2. The administration is not influenced by some influential groups. & 3.5 & 3.5 & 3.5 & 3.5 & 2 & $\mathrm{AO}$ \\
\hline 3. Teachers do not feel pressure from the community. & 3.3 & 3.6 & NA & 3.5 & 2 & $\mathrm{AO}$ \\
\hline 4. The school is protected from outside pressures. & 3.4 & 3.5 & NA & 3.5 & 2 & $\mathrm{AO}$ \\
\hline 5. The school is protected from the demands of the public. & 3.5 & 3.5 & NA & 3.5 & 2 & $\mathrm{AO}$ \\
\hline
\end{tabular}


6. Teachers express pride in their school.

7. Community demands are not accepted, especially when they are not consistent with the educational program.

\section{AVERAGE WEIGHTED MEAN}

\begin{tabular}{l|l|l|l|l|l}
3.6 & 3.4 & 3.4 & 3.5 & 2 & $\mathrm{AO}$ \\
\hline 3.6 & 3.7 & $\mathrm{NA}$ & 3.7 & 1 & $\mathrm{AO}$ \\
$\mathbf{3 . 5}$ & $\mathbf{3 . 5}$ & $\mathbf{3 . 5}$ & 3.5 & & $\mathrm{AO}$ \\
\hline
\end{tabular}

Data showed that respondents rated their schools' institutional integrity with an average weighted mean of 3.5 described as "always observed". Among the items asked, item number 7 got the highest average weighted mean of 3.7. The result of the study implies that the educational mission of the school can go forward without undue influence from outside groups; therefore, it can be assumed that the schools are "very healthy".

The study of Hoy and Tarter (1997) supports the findings of this study stating that healthy schools have teachers who are protected from unreasonable and hostile outside forces and the school is not vulnerable to narrow, vested interests of community groups.

Table 1.3 Level of School Climate in terms of Collegial Leadership

\begin{tabular}{|c|c|c|c|c|c|c|}
\hline \multirow[t]{2}{*}{ SCHOOL CLIMATE } & \multicolumn{4}{|c|}{ Weighted Mean Score } & \multirow[b]{2}{*}{$\mathrm{R}$} & \multirow{2}{*}{$\mathrm{DI}$} \\
\hline & $\mathrm{T}$ & $\operatorname{Pr}$ & $\mathrm{Pa}$ & Ave & & \\
\hline $\begin{array}{l}\text { 1. The principal explores all sides of topics and admits that other } \\
\text { opinions exist. }\end{array}$ & 3.3 & 3.6 & NA & 3.5 & 3 & $\mathrm{AO}$ \\
\hline 2. The principal treats all faculty members as his or her equal. & 3.6 & 3.7 & NA & 3.7 & 1 & $\mathrm{AO}$ \\
\hline 3. The principal is friendly and approachable. & 3.8 & 3.8 & 3.5 & 3.7 & 1 & $\mathrm{AO}$ \\
\hline 4. The principal puts suggestions made by the faculty into operation. & 3.4 & 3.5 & 3.3 & 3.4 & 4 & $\mathrm{AO}$ \\
\hline 5. The principal is willing to make changes. & 3.6 & 3.6 & 3.7 & 3.6 & 2 & $\mathrm{AO}$ \\
\hline 6. The principal discusses classroom issues with the teacher. & 3.5 & 3.6 & 3.7 & 3.6 & 2 & $\mathrm{AO}$ \\
\hline $\begin{array}{l}\text { 7. The principal goes out of his/her way to give appreciation to } \\
\text { teachers. }\end{array}$ & 3.5 & 3.8 & 3.5 & 3.6 & 2 & $\mathrm{AO}$ \\
\hline 8. The principal lets the faculty know what is expected of them. & 3.5 & 3.6 & 3.7 & 3.6 & 2 & $\mathrm{AO}$ \\
\hline 9. The principal conducts meaningful evaluation. & 3.5 & 3.6 & NA & 3.6 & 2 & $\mathrm{AO}$ \\
\hline 10. The principal looks out for the personal welfare of faculty and staff. & 3.5 & 3.5 & 3.7 & 3.6 & 2 & $\mathrm{AO}$ \\
\hline AVERAGE WEIGHTED MEAN & 3.5 & 3.6 & 3.6 & 3.6 & 2 & $\mathrm{AO}$ \\
\hline
\end{tabular}

Data revealed that respondents perceived their school to have "always observed" the items listed under collegial leadership with an average weighted mean of 3.6. Findings indicate that the schools under study can be considered "very healthy" since it has been noted that principals always set an open, friendly, and supportive tone, yet hold high expectations for performance of teachers and students.

Thornton (2005) supports this study who asserts that an open school with a healthy climate has a principal that listens and is open to teachers' suggestions. Moreover, supportive principals respect the professional competence of their staff and exhibit both a professional and personal interest in each teacher.

Table 1.4 Level of School Climate in terms of Resource Influence

\begin{tabular}{|c|c|c|c|c|c|c|}
\hline \multirow{2}{*}{$\begin{array}{l}\text { SCHOOL CLIMATE } \\
\text { Resource Influence }\end{array}$} & \multicolumn{4}{|c|}{ Weighted mean score } & \multirow{2}{*}{$\mathrm{R}$} & \multirow{2}{*}{$\mathrm{DI}$} \\
\hline & $\mathrm{T}$ & $\operatorname{Pr}$ & $\mathrm{Pa}$ & Ave & & \\
\hline 1. The principal gets what he/she asks from superiors. & 3.3 & 3.4 & 3.4 & 3.4 & 1 & $\mathrm{AO}$ \\
\hline 2. Extra materials are available if requested. & 3.4 & 3.4 & 3.4 & 3.4 & 1 & $\mathrm{AO}$ \\
\hline 3. The principal is able to influence the actions of his/her superiors. & 3.3 & 3.4 & 3.5 & 3.4 & 1 & $\mathrm{AO}$ \\
\hline 4. Teachers are provided with adequate materials for their classrooms. & 3.4 & 3.5 & 3.3 & 3.4 & 1 & $\mathrm{AO}$ \\
\hline
\end{tabular}




\begin{tabular}{|c|c|c|c|c|c|c|c|}
\hline 5. & $\begin{array}{l}\text { The principal's recommendations are given serious considerations by } \\
\text { his/her superiors. }\end{array}$ & 3.3 & 3.4 & NA & 3.4 & 1 & $\mathrm{AO}$ \\
\hline & AVERAGE WEIGHTED MEAN & 3.3 & 3.4 & 3.4 & 3.4 & & $\mathrm{AO}$ \\
\hline
\end{tabular}

Data showed that principals of the respondent schools have high resource influence since the average weighted mean is 3.4, described as "always observed". This means that the school is "very healthy" since findings revealed that the principals are able to influence superiors to provide adequate classroom supplies in a timely manner, and that extra instructional supplies can easily be obtained when needed.

Table 1.5 Level of School Climate in terms of Academic Emphasis

\begin{tabular}{|c|c|c|c|c|c|c|}
\hline SCHOOL CLIMATE & & ghted & hean & & $\mathrm{D}$ & $\mathrm{DI}$ \\
\hline Academic Emphasis & $\mathrm{T}$ & $\operatorname{Pr}$ & $\mathrm{Pa}$ & Ave & $\mathrm{K}$ & \\
\hline 1. The school sets high standards for academic performance. & 3.4 & 3.9 & NA & 3.7 & 2 & $\mathrm{AO}$ \\
\hline 2. Students respect others who get good grades. & 3.3 & 3.7 & 3.4 & 3.5 & 4 & $\mathrm{AO}$ \\
\hline 3. The principal maintains definite standards of performance. & & & $\mathrm{NA}$ & 3.7 & 2 & $\mathrm{AO}$ \\
\hline $\begin{array}{l}\text { 4. Teachers in this school believe that their student s have the ability to } \\
\text { achieve academically. }\end{array}$ & 3.5 & 3.5 & 3.6 & 3.5 & 4 & $\mathrm{AO}$ \\
\hline 5. Students seek extra work so they can get good grades. & 3.3 & 3.5 & 3.7 & 3.5 & 4 & $\mathrm{AO}$ \\
\hline 6. Students try hard to improve on previous work. & 3.3 & 3.5 & 3.8 & 3.5 & 4 & $\mathrm{AO}$ \\
\hline 7. Academic achievement is recognized and acknowledged by the school. & 3.7 & 3.8 & 3.9 & 3.8 & 1 & $\mathrm{AO}$ \\
\hline $\begin{array}{l}\text { 8. Students in this school can achieve the goals that have been set for } \\
\text { them. }\end{array}$ & 3.3 & 3.6 & NA & 3.5 & 4 & $\mathrm{AO}$ \\
\hline 9. The learning environment is orderly and serious. & 3.5 & 3.7 & 3.9 & 3.7 & 2 & $\mathrm{AO}$ \\
\hline 10. Students are cooperative during class instruction. & 3.3 & 3.7 & 3.8 & 3.6 & 3 & $\mathrm{AO}$ \\
\hline AVERAGE WEIGHTED MEAN & 3.4 & 3.7 & 3.7 & 3.6 & & $\mathrm{AO}$ \\
\hline
\end{tabular}

The average weighted mean for academic emphasis is 3.6, described as "always observed" with item number 7 being the highest and items number $2,4,5,6$, and 8 being the lowest. Results denote that the respondent schools are "very healthy" since data proved that teachers have high expectations to students and that students meet these high expectations through hard work and cooperation. It also indicates that students who achieve good grades are respected by their peers.

Table 1.6 Level of School Climate in Respondent Schools

\begin{tabular}{l|c|c|c|c|c|c}
\hline \hline \multirow{2}{*}{ SCHOOL CLIMATE } & \multicolumn{4}{|c|}{ Weighted mean score } & \multirow{2}{*}{$\mathrm{R}$} & \multirow{2}{*}{$\mathrm{DI}$} \\
\cline { 2 - 6 } & $\mathrm{T}$ & $\mathrm{Pr}$ & $\mathrm{Pa}$ & Ave. & & \\
\hline Teacher Affiliation & 3.7 & 3.9 & 3.9 & 3.8 & 1 & $\mathrm{AO}$ \\
\hline Institutional Integrity & 3.5 & 3.5 & 3.5 & 3.5 & 3 & $\mathrm{AO}$ \\
\hline Collegial Leadership & 3.5 & 3.6 & 3.6 & 3.6 & 2 & $\mathrm{AO}$ \\
\hline Resource Influence & 3.3 & 3.4 & 3.4 & 3.4 & 4 & $\mathrm{AO}$ \\
\hline Academic Emphasis & 3.4 & 3.7 & 3.7 & 3.6 & 2 & $\mathrm{AO}$ \\
\hline
\end{tabular}

As shown, it can be implied that the schools under study is classified as very healthy schools since their average weighted mean ranged from 3.4 to 3.8 which means that respondents always observed the indicators of a healthy school in their respective stations. The findings indicate that the schools' organizational structure is not subject to undue pressure from the community; with teaching staff who are dedicated; principals who give dynamic guidance; learners who are motivated, and have goals that are attainable; as well as sufficient resources.

This result adheres to the standards of a healthy school set by Hoy and Tarter (1997). Accordingly, a healthy elementary school is a pleasant place, protected from unwarranted intrusion, having teachers who like the school, the students, and each other. Students are diligent in their learning; principal are approachable, supportive and considerate, yet establish high standards of teacher performance. 
Table 2.1 Level of Teachers' Commitment to School

\section{TEACHERS' COMMITMENT}

\section{Teachers' Commitment to School}

1. Teachers are willing to put in a great deal of effort than what is normally expected in order to help this school be successful.

\begin{tabular}{|c|c|c|c|c|c|c|c|}
\hline & normally expected in order to help this school be successtul. & 3.6 & 3.6 & NA & 3.6 & 3 & $\mathrm{HC}$ \\
\hline 2. & Teachers are loyal to this school. & 3.7 & 3.8 & 3.9 & 3.8 & 1 & $\mathrm{HC}$ \\
\hline 3. & Teachers are proud to tell others that they are part of this school. & 3.7 & 3.7 & 4.0 & 3.8 & 1 & $\mathrm{HC}$ \\
\hline 4. & Teachers are inspired to perform their best in the school. & 3.8 & 3.6 & NA & 3.7 & 2 & $\mathrm{HC}$ \\
\hline 5. & Teachers really care about the fate of this school. & 3.8 & 3.7 & 3.9 & 3.8 & 1 & $\mathrm{HC}$ \\
\hline & $\begin{array}{l}\text { Teachers feel that this school is the best of all possible schools for } \\
\text { which to work. }\end{array}$ & 3.6 & 3.5 & NA & 3.6 & 3 & $\mathrm{HC}$ \\
\hline & AVERAGE WEIGHTED MEAN & 3.7 & 3.7 & 3.9 & 3.8 & & $\mathrm{HC}$ \\
\hline
\end{tabular}

The table illustrates that teachers are highly committed to their school as perceived by all groups of respondents since it got an average weighted mean of 3.8. Of the items asked, items number 2, 3 and 5 got the highest average weighted mean while items number 1 and 6 got the lowest. Based on the findings, it can be noted that teachers under study are proud and loyal to their school and are willing to exert more effort in order to help their school be successful.

The study of Najeemah (2012) supports this findings stating that committed teachers are highly committed to their school and are expected to engage in school activities to achieve the school goals, exert considerable effort beyond minimal expectations, and remain working within the organization.

Table 2.2 Level of Teachers' Commitment to Profession

\begin{tabular}{|c|c|c|c|c|c|c|}
\hline \multirow{2}{*}{$\begin{array}{r}\text { TEACHERS' COMMITMENT } \\
\text { Teachers' Commitment to Teaching Profession } \\
\end{array}$} & \multicolumn{4}{|c|}{ Weighted mean score } & \multirow{2}{*}{$\mathrm{R}$} & \multirow{2}{*}{ DI } \\
\hline & $\mathrm{T}$ & $\operatorname{Pr}$ & $\mathrm{Pa}$ & Ave & & \\
\hline 1. Teachers accomplish their job with enthusiasm. & 3.5 & 3.7 & NA & 3.6 & 3 & $\mathrm{HC}$ \\
\hline 2. Teachers are proud of being a teacher. & 3.8 & 3.7 & 3.9 & 3.8 & 1 & $\mathrm{HC}$ \\
\hline 3. Teachers enjoy teaching. & 3.6 & 3.5 & 3.8 & 3.6 & 3 & $\mathrm{HC}$ \\
\hline $\begin{array}{l}\text { 4. Sometimes teachers lie awake at night thinking ahead to the next } \\
\text { day's work. }\end{array}$ & 3.7 & 3.6 & 3.9 & 3.7 & 2 & $\mathrm{HC}$ \\
\hline $\begin{array}{l}\text { 5. If I would get a job different from being a teacher and paying the } \\
\text { same amount, I won't take it. }\end{array}$ & 3.3 & 3.4 & NA & 3.4 & 4 & $\mathrm{HC}$ \\
\hline 6. The best decision that I have ever made is to become a teacher. & 3.6 & 3.6 & NA & 3.6 & 3 & $\mathrm{HC}$ \\
\hline AVERAGE WEIGHTED MEAN & 3.7 & 3.7 & 3.9 & 3.8 & & $\mathrm{HC}$ \\
\hline
\end{tabular}

The average weighted mean for teachers' commitment to the teaching profession is 3.8, which depicts high level of commitment. Among the items presented, the second item got the highest average weighted mean of 3.8 which implies that teachers are proud of their profession. Results showed that teachers reflect a high degree of psychological attachment with their duty in their classroom by accomplishing their job with enthusiasm and by being proud as a teacher.

Table 2.3 Level of Teachers' Commitment to Pupils

\begin{tabular}{|c|c|c|c|c|c|c|}
\hline TEACHERS' COMMITMENT & We & hted & ean $s$ & ore & $\mathrm{D}$ & סח \\
\hline Teachers' Commitment to Pupils & $\mathrm{T}$ & $\operatorname{Pr}$ & $\mathrm{Pa}$ & Ave & $n$ & DI \\
\hline $\begin{array}{l}\text { 1. Teachers in the school are responsible in ensuring good social } \\
\text { relations among pupils. }\end{array}$ & 3.7 & 3.6 & 4.0 & 3.8 & 1 & $\mathrm{HC}$ \\
\hline 2. Teachers in the school are responsible in ensuring pupils' success. & 3.8 & 3.4 & NA & 3.6 & 3 & $\mathrm{HC}$ \\
\hline
\end{tabular}




\begin{tabular}{l|c|c|c|c|c|c}
\hline \hline $\begin{array}{l}\text { 3. Teachers feel obliged to mediate among the rival groups of the } \\
\text { pupils. }\end{array}$ & 3.7 & 3.5 & 4.0 & 3.7 & 2 & $\mathrm{HC}$ \\
\hline $\begin{array}{l}\text { 4. Teachers try to do their best for the unsuccessful pupils. } \\
\text { 5. Teachers give their full support to their pupils when they need it. }\end{array}$ & 3.7 & 3.5 & 4.0 & 3.7 & 2 & $\mathrm{HC}$ \\
\hline $\begin{array}{l}\text { 6. Teachers feel glad seeing their pupils succeed. } \\
\text { AVERAGE WEIGHTED MEAN }\end{array}$ & 3.9 & 3.7 & $\mathrm{NA}$ & 3.7 & 2 & $\mathrm{HC}$ \\
\hline
\end{tabular}

There is a high level of teachers' commitment since the average weighted mean is 3.8. Items 1 and 6 got the highest average weighted mean which means that teachers are glad upon seeing their pupils succeed. This indicates that teachers understand and are aware of child development and sees every child as unique whole individuals. It also means that teachers do their best for the pupils by ensuring good social relationship among them and giving full support when they need it.

Table 2.4 Level of Teachers' Commitment to Work Group

\begin{tabular}{|c|c|c|c|c|c|c|}
\hline \multirow{2}{*}{$\begin{array}{c}\text { TEACHERS' COMMITMENT } \\
\text { Teachers' Commitment to Work Group }\end{array}$} & \multicolumn{4}{|c|}{ Weighted Mean Score } & \multirow{2}{*}{$\mathrm{R}$} & \multirow{2}{*}{$\mathrm{DI}$} \\
\hline & $\mathrm{T}$ & $\operatorname{Pr}$ & $\mathrm{Pa}$ & Ave & & \\
\hline 1. Teachers spend time with other teachers during break time. & 3.4 & 3.4 & 3.7 & 3.5 & 2 & $\mathrm{HC}$ \\
\hline 2. $\quad$ Teachers are proud of their colleagues. & 3.6 & 3.4 & NA & 3.5 & 2 & $\mathrm{HC}$ \\
\hline $\begin{array}{l}\text { 3. Teachers have the perception of being felt as the close friend by the } \\
\text { other teachers in the school. }\end{array}$ & 3.5 & 3.6 & NA & 3.6 & 1 & $\mathrm{HC}$ \\
\hline 4. Teachers consider other teachers in the school as their best friends. & 3.5 & 3.5 & NA & 3.5 & 2 & $\mathrm{HC}$ \\
\hline $\begin{array}{l}\text { 5. Teachers have harmonious relationship with other teachers out of the } \\
\text { school. }\end{array}$ & 3.5 & 3.3 & 3.8 & 3.5 & 2 & $\mathrm{HC}$ \\
\hline 6. Teachers feel that their colleagues can be trusted. & 3.4 & 3.5 & 3.8 & 3.6 & 1 & $\mathrm{HC}$ \\
\hline $\begin{array}{l}\text { AVERAGE WEIGHTED MEAN } \\
\end{array}$ & 3.5 & 3.5 & 3.8 & 3.5 & & $\mathrm{HC}$ \\
\hline
\end{tabular}

Teachers' commitment to work group is notably high with an average weighted mean of 3.5. Looking into details, results show that items 3 and 6 got a higher average weighted mean than the other items. It means that teachers have harmonious relationship in and out of the school and they establish a strong feeling of trust and confidence to each other.

Similarly, the findings of the current study agree to the findings of Singleton (2006) that teachers were seen to be pleased with being with other teachers during breaks, had a proper pride of their friends, perceived each other as close friends, and had the same relationship with each other out of the school.

Table 2.5 Level of Teachers' Commitment

\begin{tabular}{l|c|c|c|c|c|c}
\hline \multirow{2}{*}{ TEACHERS' COMMITMENT } & \multicolumn{4}{|c|}{ Weighted mean score } & \multirow{2}{*}{$\mathrm{R}$} & \multirow{2}{*}{$\mathrm{DI}$} \\
\cline { 2 - 7 } & $\mathrm{T}$ & $\mathrm{Pr}$ & $\mathrm{Pa}$ & Ave. & & \\
\hline School & 3.7 & 3.7 & 3.9 & 3.8 & 1 & $\mathrm{HC}$ \\
\hline Teaching Profession & 3.7 & 3.7 & 3.9 & 3.8 & 1 & $\mathrm{HC}$ \\
\hline Pupils & 3.7 & 3.6 & 4.0 & 3.8 & 1 & $\mathrm{HC}$ \\
\hline Work Group & 3.5 & 3.5 & 3.8 & 3.6 & 2 & $\mathrm{HC}$ \\
\hline
\end{tabular}

The average weighted mean of 3.6 denotes high commitment based on the scale provided. It can be claimed that teachers are highly committed to school, teaching profession, pupils and work group. Interestingly, the findings indicate that amidst the challenges that teachers face like higher demand of knowledge and skills in handling pupils from diverse backgrounds and abilities, teachers invest more effort in promoting high quality of teaching to optimize student outcomes. Consequently, the level of effort exerted by teachers in promoting high quality of teaching are reflected by their commitment to work, school, pupils and work group.

The study is consistent with the study done by Smith (2009) who found out that committed teachers are more hard working, less tardy, and less inclined to leave the workplace. They devote more time to extracurricular activities to accomplish the goals of the 
organization and influence student achievement. Lastly, they believe and act upon the goals of the school and exert more efforts beyond personal interests.

The following figures present the school performance indicators of the respondent schools. It takes into account the performance indicators of the schools like graduation, retention, promotion, participation, repetition, dropout, and failure rates of these schools.

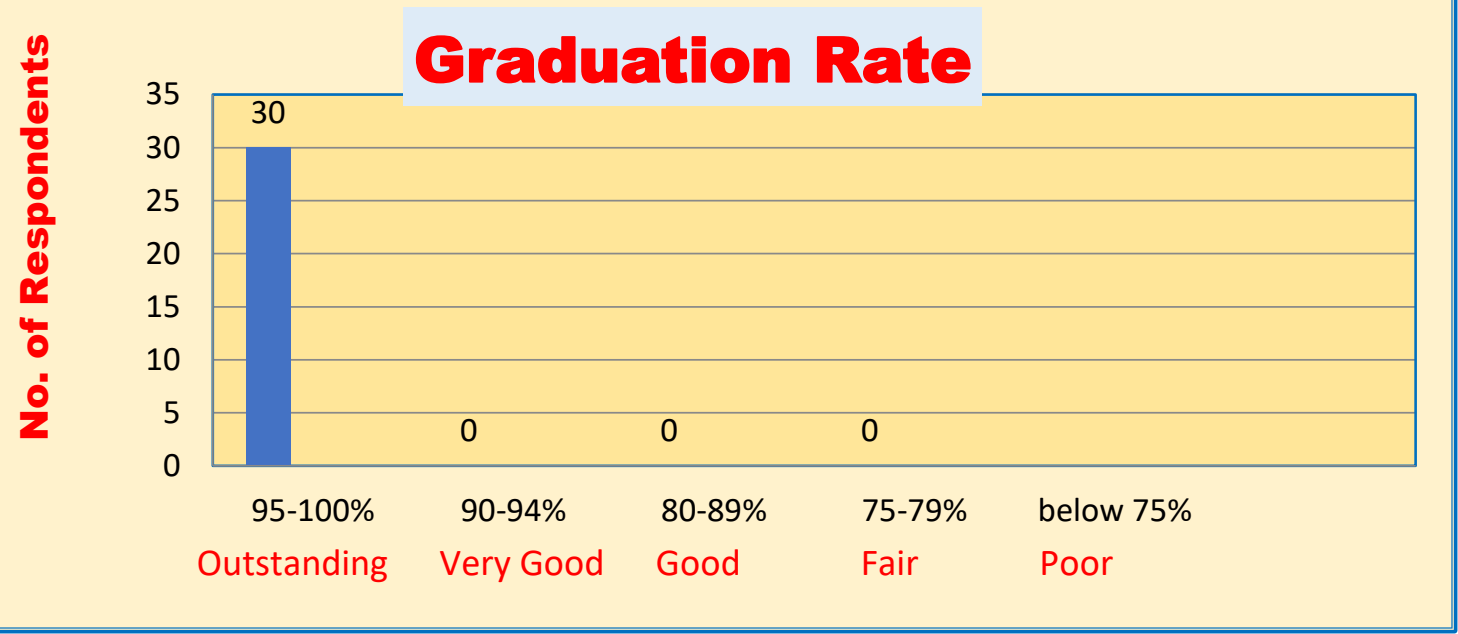

Figure 1. Graduation Rate of Respondent Schools

The figure suggests that all the respondent-schools have graduation rates that range from $95-100 \%$. This means that these schools have an outstanding performance in terms of graduation rate. This seems to imply that schools encouraged each pupil to succeed by having a powerful influence on their motivation to learn.

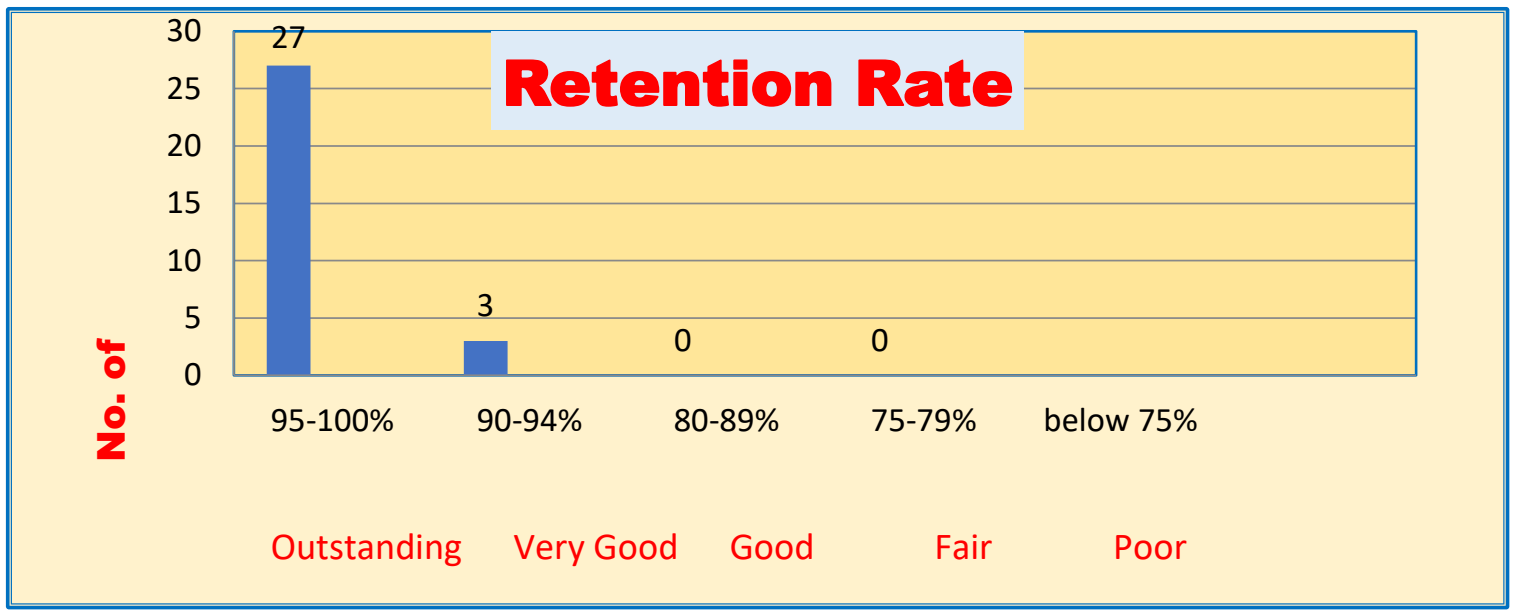

Figure 2. Retention Rate of the Respondent Schools

Twenty-seven (27) out of 30 respondent schools have retention rates ranging from $95-100 \%$ while the remaining schools have retention rates ranging from $90-94 \%$. This implies that schools have improved holding power by maintaining healthy environment and healthy relationship between pupils and school staff. 


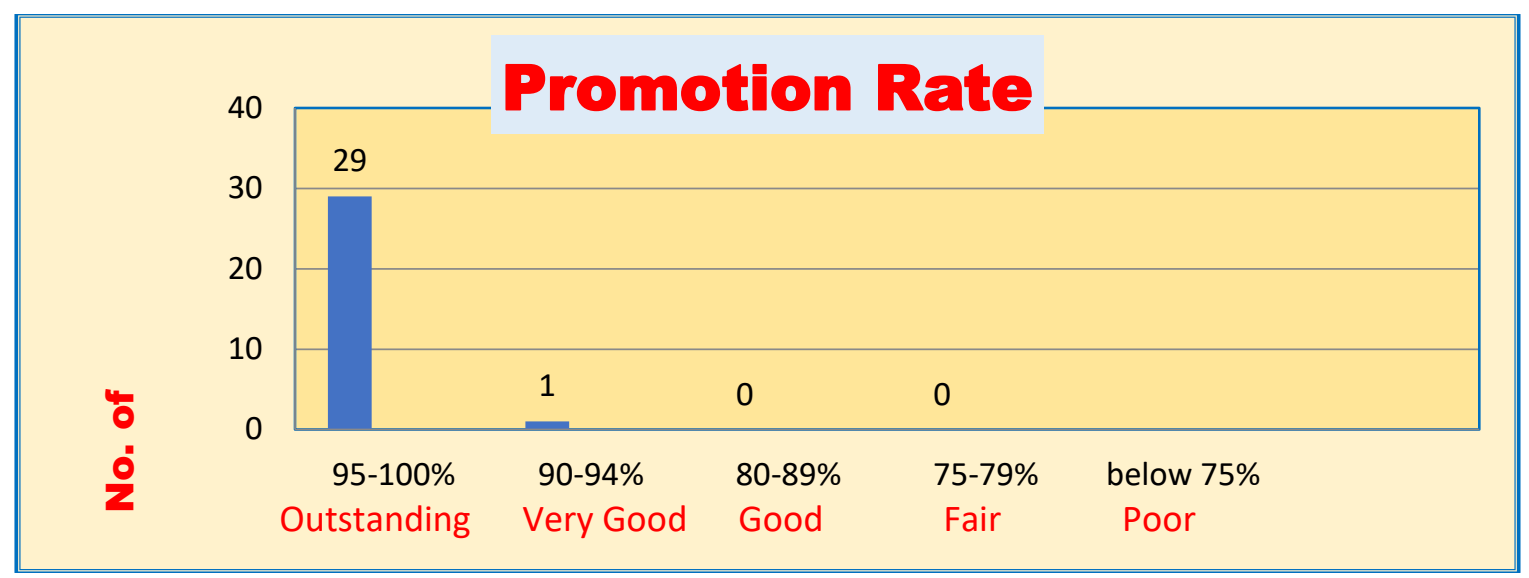

Figure 3. Promotion Rate of Respondent Schools

Twenty-nine (29) out of 30 respondent schools have a promotion rate ranging from $95-100 \%$. It indicates that these schools have an outstanding performance in terms of promotion rate. This implies that schools are responsible in improving well-being and academic outcomes of pupils.

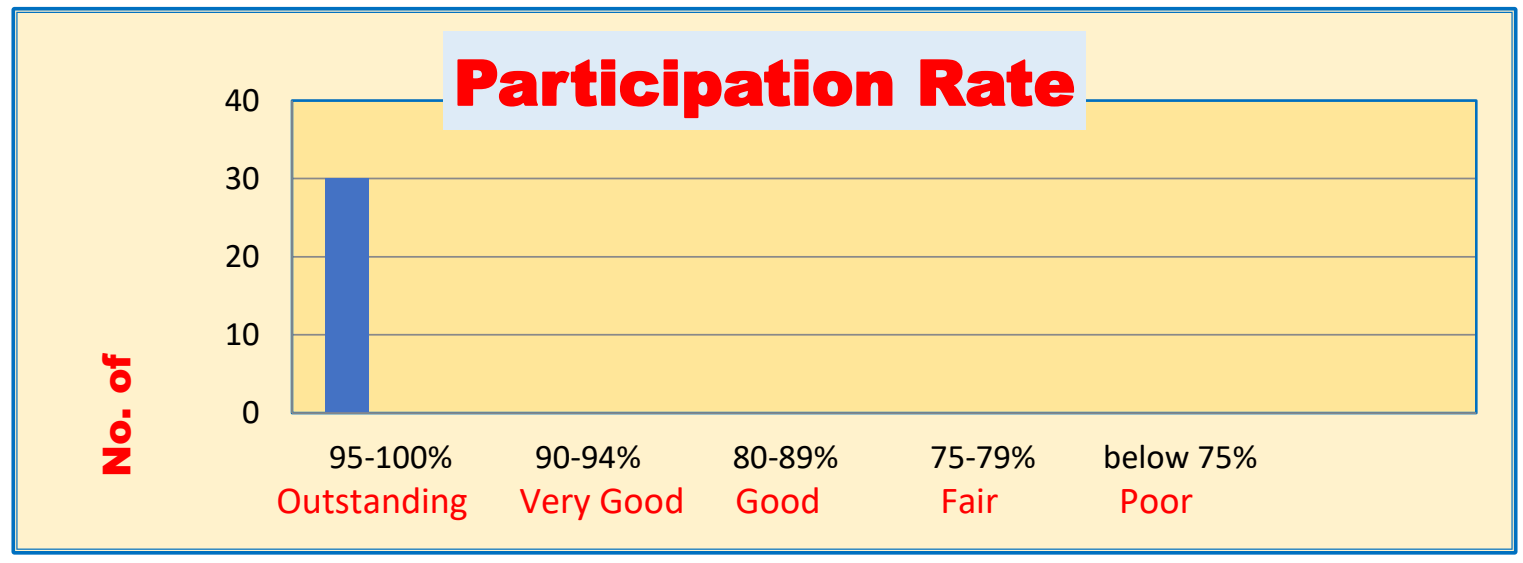

Figure 4. Participation Rate of Respondent Schools

Results showed that all respondent schools have an outstanding participation rates ranging from 95-100\%. It implies that school-age children in the immediate community are motivated to learn and improve themselves.

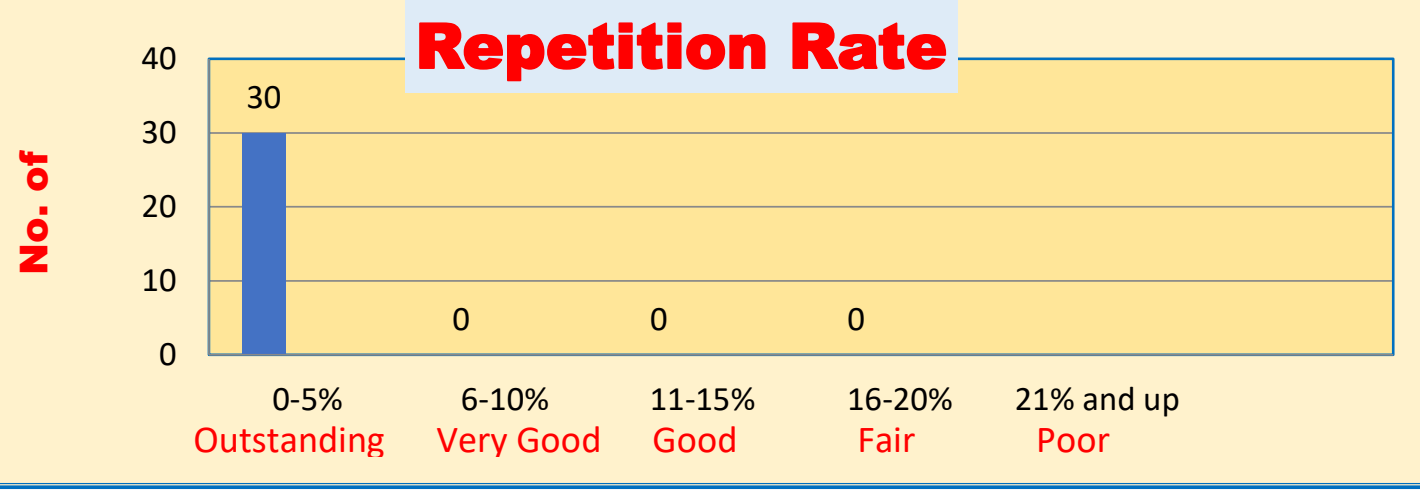

Figure 5. Repetition Rate of Respondent Schools

All school respondents have failure rates ranging from $0-5 \%$ of the pupil population. It signifies an outstanding performance which means that teachers were able to provide a healthy learning environment which promotes pupils' ability to learn. 


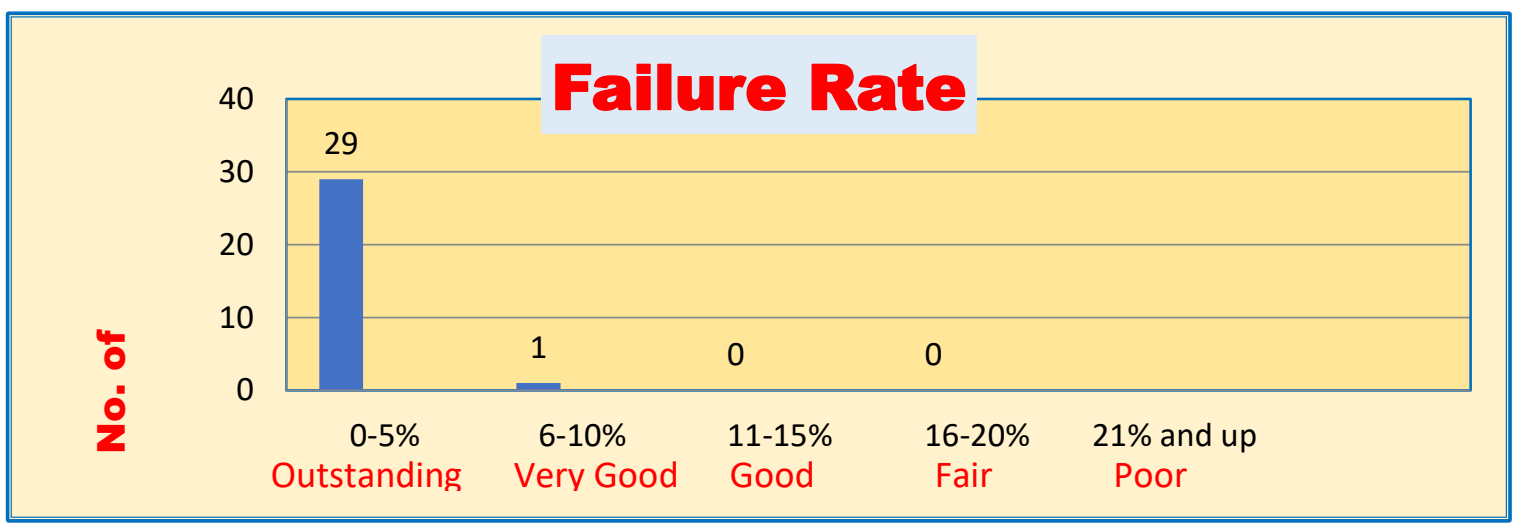

Figure 6. Failure Rate of Respondent Schools

Results revealed that 29 out of 30 school respondents have a failure rate ranging from $0-5 \%$ of the total pupil population. This indicates an outstanding performance as it means that only few pupils failed a grade level. It further indicates that the schools have exerted its utmost effort for the success of its pupils.

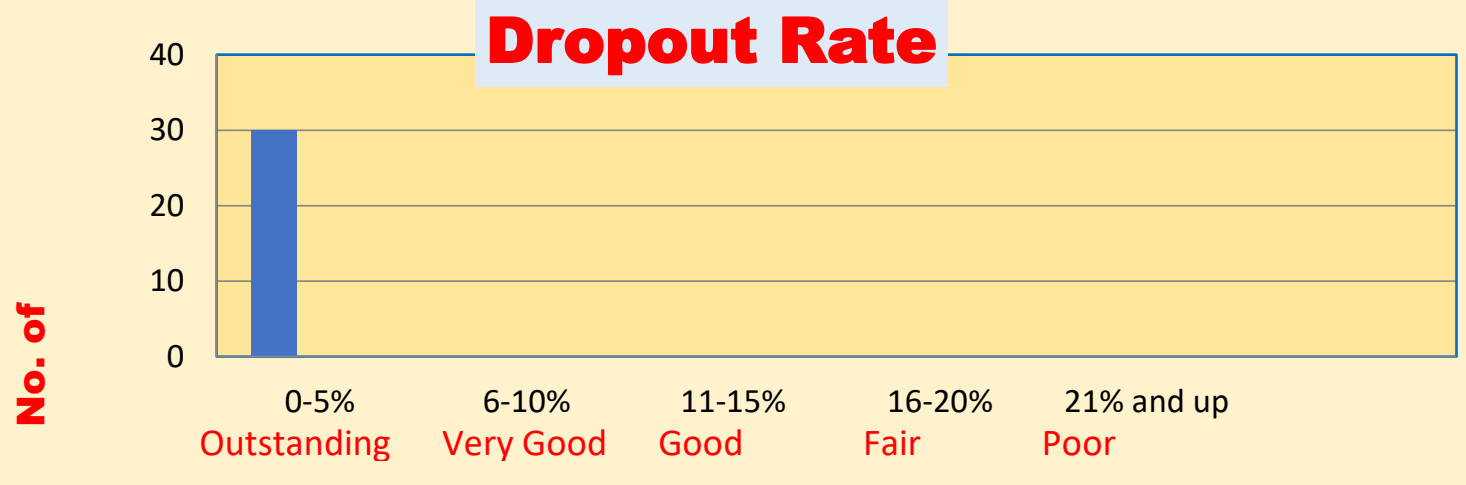

Figure 7. Dropout Rate of School Respondents

Findings revealed that dropout rates in all school respondents range from 0-5\%. This signifies an outstanding performance which indicates that schools provide varied opportunities to meet the needs of all learners.

Table 3.1 Analysis on the relationship between School Climate and Teachers' Commitment

\begin{tabular}{c|c|c|c|c|c|c}
\hline \hline $\begin{array}{c}\text { Sources of } \\
\text { Relationship }\end{array}$ & $\begin{array}{c}\text { Pearson } \\
\mathrm{r}\end{array}$ & Description & $\begin{array}{c}\text { T } \\
\text { Computed Value } \\
\text { (at 0.05 level of } \\
\text { significance) }\end{array}$ & $\begin{array}{c}\text { Critical } \\
\text { Value }\end{array}$ & Interpretation & Decision \\
\hline $\begin{array}{c}\text { Teachers' } \\
\text { Perception }\end{array}$ & .60 & $\begin{array}{c}\text { Moderate } \\
\text { correlation }\end{array}$ & 3.96 & 2.048 & Significant & Reject $\mathrm{H}_{\circ}$ \\
\hline $\begin{array}{c}\text { Principals' } \\
\text { Perception }\end{array}$ & .44 & $\begin{array}{c}\text { Moderate } \\
\text { correlation }\end{array}$ & 2.59 & 2.048 & Significant & Reject $\mathrm{H}_{\circ}$ \\
\hline Parents' Perception & .58 & $\begin{array}{c}\text { Moderate } \\
\text { correlation }\end{array}$ & 3.77 & 2.048 & Significant & Reject $\mathrm{H}_{\circ}$ \\
\hline
\end{tabular}

The computed t value 3.96, 2.59, and 3.77 from teachers', principals' and parents' perception were higher than the critical value at $5 \%$ which was 2.048. It implies a significant relationship between the two variables which means that teachers' commitment was affected by teacher affiliation, institutional integrity, collegial leadership, resource influence and academic emphasis. Therefore, the null hypothesis is rejected. 
This result coincides with the findings of Najeemah (2012) that school climate has a significant relationship with the teachers' commitment. Dimensions such as collaborative leadership, teachers' professional behavior, and working pressure have positive significant relationship with teachers' commitment. This means that school climate plays an important role in influencing the behavior and achievement of the community in the school.

Table 6.2 Analysis on the relationship between School Climate and School Performance

\begin{tabular}{c|c|c|c|c|c|c}
\hline \hline $\begin{array}{c}\text { Sources of } \\
\text { Relationship }\end{array}$ & $\begin{array}{c}\text { Spearman } \\
\mathrm{R}\end{array}$ & Description & $\begin{array}{c}\mathrm{T} \\
\text { Computed } \\
\text { Value }\end{array}$ & $\begin{array}{c}\text { Critical } \\
\text { Value }\end{array}$ & Interpretation & Decision \\
\hline Teachers' Perception & .43 & $\begin{array}{c}\text { Moderate } \\
\text { correlation }\end{array}$ & 2.52 & .306 & Significant & Reject $\mathrm{H}_{\circ}$ \\
\hline Principals' Perception & .95 & $\begin{array}{c}\text { Very high } \\
\text { correlation }\end{array}$ & 16.1 & .306 & Significant & Reject $\mathrm{H}_{\circ}$ \\
\hline Parents' Perception & .76 & $\begin{array}{c}\text { High } \\
\text { correlation }\end{array}$ & 6.19 & .306 & Significant & Reject $\mathrm{H}_{\circ}$ \\
\hline
\end{tabular}

The table indicates that there is a significant relationship between school climate and school performance since the computed $t$ values $2.52,16.1$, and 6.19 from teachers', principals' and parents' perceptions were higher than the critical value at $5 \%$ which was .306. Therefore, the null hypothesis is rejected.

This study affirms the findings of Goddard and Kelley (2005) that school climate affects its school performance. Moreover, Cohen (2006) stated that school climate affects its success. Previous studies have found school climate to exert significant influence over school performance. On the study of Garner (2008), it has been summed up that the aspects of school climate that are most strongly related to school outcomes are high expectations, orderly school environment, high morale, and positive treatment of students. Similarly, Griffith (2002) found that individual and school level perceptions of climate were positively associated with academic achievement and attendance. Previous research regarding this construct has repeatedly demonstrated positive relationship between school climate and academic achievement, as well as decreased instances of misconduct and aggression (Singleton, 2006).

\section{Conclusions and Recommendations}

This paper examined the level of school climate among selected schools, their teachers' level of commitment, and the school performance. It then explored how teacher's commitment and school performance were affected by school climate. Based on the findings, this research concludes that school climate had a significant relationship to teachers' commitment and school performance. A positive school climate promotes high teacher commitment and better school performance.

On the basis of the foregoing findings and conclusions, the following recommendations are presented:

Schools Division Superintendent may provide appropriate curriculum, counseling, mentoring, and training sessions for teachers, students, parents, and administrators in order to establish and maintain positive school climate. School administrators may demonstrate an interest in the personal goals, achievements and problems of teachers and pupils and support them in their academic and extracurricular activities. Teachers may share and communicate high expectations for pupils' success and maintain appropriate pupil behavior as an essential precondition of learning. Pupils may take responsibility for their own behavior, treat each other with kindness and respect, and learn the value of productive work and good citizenship. Parents may create a partnership with the school and continue to be engaged throughout their children's school years to have a better understanding of what is acceptable and expected in the school's environment.

As with the majority of studies, the design of the current study is subject to limitations. The respondents considered in the study were only principals, teachers and parents. Future researchers may replicate this study including pupils as participants and record their perceptions and comments concerning school climate and teachers' commitment. 


\section{References}

[1] Barth, R. (2001). Learning by Heart. San Francisco, CA: Jossey Bass Inc. https://shorturl.at/uDFK1

[2] Brookover, W.B., Schweitzer, J.H., Schneider, J.M., Beady, C.H., Flood, P.K., Wisenbaker, J.M. (1978). Elementary School Social Climate and School Achievement. American Educational Research Journal, 15(2), 301-318. doi:10.3102/00028312015002301

[3] Celep, C. (2000). Teachers' organizational commitment in educational organizations. National Forum of Teacher Education Journal, 10(3). Retrieved from http://files.eric.ed.gov/fulltext/ED452179.pdf

[4] Cohen, A. (2000). The relationship between commitment forms and work outcomes: A comparison of three models. Human Relations, 53, 387-417. https://journals.sagepub.com/doi/10.1177/0018726700533005

[5] Cohen, J., Mccabe, E.M., Michellii, N.M., Pickeral, T. (2009). School Climate: Research, Policy, Practice and Teacher Education. https://www.researchgate.net/publication/235420504 School Climate Research Policy Teacher Education and Practice

[6] Coladarci, T. (1992). Teachers' sense of efficacy and commitment to teaching. Journal of Experimental Education, 60, 323-337. https://www.tandfonline.com/doi/abs/10.1080/00220973.1992.9943869

[7] Dee, J.R., Henkin, A.B., Singleton, C.A. (2006). Organizational Commitment of Teachers in Urban Schools: Examining the Effects of Team Structures. Urban Education. https://journals.sagepub.com/doi/10.1177/0042085906292512

[8] Ebrahimi, M., Mohamadkhani, K. (2014). The relationship between organizational climate and job involvement among teacher of high schools in delijan city (Iran). International Journal of Management and Business Research, 4(1),65-72. https://www.semanticscholar.org/paper/The-Relationship-between-Organizational-Climate-and-EbrahimiMohamadkhani/819db3823594736bc9bec319ea36167a62c6399e\#paper-header

[9] Esposito, C. (2019). Learning in Urban Blight: School Climate and Its Effect on the School Performance of Urban, Minority, Low-Income Children. https://www.tandfonline.com/doi/abs/10.1080/02796015.1999.12085971

[10] Freiberg, H.J, (1998). Measuring School Climate. Let Me Count the Ways. www.ascd.org/publications/educationalleadership/sept98/vol56/num01/Measuring-School-Climate@-Let-Me-Count-the-Ways.aspx

[11] Firestone, W. A., Pennell, J. R. (1993). Teacher commitment, working conditions, and differential incentive policies. Review of Educational Research, 63, 489-525. https://journals.sagepub.com/doi/10.3102/00346543063004489

[12] Firestone, W. A., Rosenblum, S. (1988). Building commitment in urban high schools. Educational Evaluation and Policy Analysis, 10, $285-299$. https://journals.sagepub.com/doi/10.3102/01623737010004285

[13] Griffith, J. (1995). An Empirical Examination of a Model of Social Climate in Elementary Schools, Basic and Applied Social Psychology, 17:1-2, 97-117, DOI: 10.1080/01973533.1995.9646134

[14] Haynes, N.M. (1997). School climate as a factor in student adjustment and achievement. Journal of Educational and Psychological Consultation, 8(3), 321-329. https://shorturl.at/esBKQ

[15] Hinduja, S., \& Patchin, J. W. (2012). School climate 2.0: Preventing cyberbullying and sexting one classroom at a time. Corwin Press. https://doi.org/10.4135/9781506335438

[16] Hoy, W.K., Miskel, C.G., Tarter, C.J. (2013). Educational Administration Theory research, and practice (9th ed). https://www.academia.edu/35330690/Educational Administration Theory Wayne pdf

[17] Hoy, W.K., Tarter, C.J. (1992). Measuring the Health of the School Climate. A Conceptual Framework. NASSP Bulletin, 769547), 74-79. https://eric.ed.gov/?id=EJ452854

[18] Ibrahim, M. S., Ghavifekr, S., Ling, S., Siraj, S., Azeez, M. I. K. (2013). Can transformational leadership influence on teachers' commitment towards organization, teaching profession, and student learning? A quantitative analysis. Asia Pacific Education Review. Advance online publication. https://doi.org/10.1007/s12564-013-9308-3

[19] Joffres, C., \& Haughey, M. (2001). Elementary Teachers' Commitment Declines: Antecedents, Processes, and Outcomes. The Qualitative Report, 6(1), 1-22. https://doi.org/10.46743/2160-3715/2001.2007

[20] Kelley, R.C., Thornton, B., Daugherty, R. (2005). Relationships between measures of leadership and school climate. Education 126(1). https://eric.ed.gov/?id=EJ725153

[21] Konold, T., Cornell, D., Jia, Y., Malone, M. (2018). School Climate, Student Engagement, and Academic Achievement: A Latent Variable, Multilevel Multi-Informant Examination. https://journals.sagepub.com/doi/full/10.1177/2332858418815661

[22] Louis, K. S. (1998). Effects of teacher quality of work life in secondary schools on commitment and sense of efficacy. School Effectiveness and School Improvement, 9, 1-27.

https://www.tandfonline.com/doi/abs/10.1080/0924345980090101

[23] Louis, K. S., Smith, B. (1990). Teacher working conditions in Reyes, P. (Ed.), Teachers and their workplace: Commitment, performance and productivity (pp. 23-47). https://eric.ed.gov/?id=ED329533

[24] Mayer, D. (2006). The Changing Face of Teaching Profession. New Generations and New Ways of Working and Learning. Asia-Pacific Journal of Teacher Education. https://eric.ed.gov/?id=EJ729018

[25] Osher, D., Bear, G. G., Sprague, J. R., \& Doyle, W. (2010). How can we improve school discipline? Educational Researcher, $39(1), 48-58$. https://doi.org/10.3102/0013189X09357618

[26] Payne, A.A. (2018). Creating and Sustaining a Positive and Communal School Climate: Contemporary Research, Present Obstacles, and Future Directions.

a. $\quad$ https://www.ncjrs.gov/pdffiles1/nij/250209.pdf?ed2f26df2d9c416fbddddd2330a778c6=ixtkabetkx-icgktefa

[27] Peterson, R.L. and Skiba, R.2000). Creating school climate that prevent violence. Preventing School Failure, 44(3),122-129. https://www.researchgate.net/publication/233086566 Creating School Climates That Prevent School Violence 
[28] Raman, A., Tse Ying, L., \& Khalid, R. (2015). The Relationship between Culture and Organizational Commitment among Chinese Primary School Teachers. Mediterranean Journal Of Social Sciences, 6(2 S5), 93. Retrieved fromhttps://studylib.net/doc/11846939/

[29] Sarmiento, U.P. (2002). Educational law and the private schools-A Practical Guide for Educational Leaders and Policy Makers.

[30] Singh, K., Billingsley, B. S. (1998). Professional support and its effects on teachers' commitment. Journal of Educational Research, 91, 229239. https://www.tandfonline.com/doi/abs/10.1080/00220679809597548

[31] Shirzadi, R., Shad, J. R., Nasiri, M., Abdi, H., \& Khani, S. (2013). The relation of organizational climate and job motivation with organizational commitment of new employed teachers of physical education of educations and training administration in Kermanshah province. Advances in Environmental Biology, 4084+.

[32] https://go.gale.com/ps/anonymous?id=GALE\%7CA365687766\&sid=googleScholar\&v=2.1\&it=r\&linkaccess=abs\&issn=19950756\&p=AON $E \& S W=W$

[33] Smith, L.D. (2009). School climate and teacher commitment. https://eric.ed.gov/?id=ED514017

[34] Somech, A., Bogler, R. (2002). Antecedents and consequences of teacher organizational and professional commitment. Educational Administration Quarterly, 38, 555-577. https://journals.sagepub.com/doi/10.1177/001316102237672

[35] Thomasson, V. (2006). "A Study of the relationship between school climate and student performance on the Virginia standards of learning tests in elementary study." https://scholarscompass.vcu.edu/etd/1150/

[36] Troman, G. (2013). Primary Teacher Identity, Commitment and Career in Performative School Cultures. British Educational Research Journal. https://bera-journals.onlinelibrary.wiley.com/doi/abs/10.1080/01411920802223925

[37] Yusof, N.M. (2012). School climate and teachers' commitment: A case study of Malaysia. International journal of economics business and management studies.

a. https://www.academia.edu/2006806/School Climate and Teachers Commitment A Case Study of Malaysia

[38] Zullig, K.J., Huebner, E.S., Patton, J.M. (2010). Relationship among Climate Domains and School satisfaction.

https://doi.org/10.1002/pits.20532 